\title{
Bakiak and Interpersonal Intelligence on Physical Motor of Children in Khairani Kindergarten of Aceh Besar
}

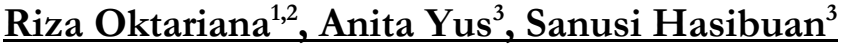 \\ ${ }^{1}$ Lecturer in STKIP Bina Bangsa Getsempena \\ ${ }^{2}$ Master Student in State University of Medan (UNIMED), Medan, Indonesia \\ ${ }^{3}$ Lecturer in State University of Medan (UNIMED), Medan, Indonesia \\ Email: riza@stkipgetsempena.ac.id
}

\begin{abstract}
:
Physical motor development is one of the five aspects of early childhood development, to achieve the motoric development, especially rough motoric is done through games. Play activities can stimulate a children's physical motor development, and become one of the other important factors in improving a children's psychic interpersonal intelligence. Based on this background, the researchers chose the title "Bakiak and Interpersonal Intelligence on Physical Motor of Children in Khairani Kindergarten of Aceh Besar". Problems formulation in this study are: Is there any effect of bakiak game on children's physical motor development, is there any effect of interpersonal intelligence on a children's physical motor development, and is there any interaction of bakiak game and interpersonal intelligence on a children's physical motor development. The research objectives are: To determine the effect of bakiak game on children's physical motor, to determine the effect of interpersonal intelligence on children's physical motor development and to determine the interaction of bakiak game and interpersonal intelligence on children's physical motor development. The location of the study was conducted at Khairani Kindergarten in Aceh Besar located in Lubok Batee village, Ingin Jaya Subdistricr, Aceh Besar District. This study was conducted on 15 October to 15 December 2018. The research subject of children's group B which amounted to 30 people, consisting of B1 (15 people) and B2 (15 people). This study was conducted by using experimental methods and research design with treatment by level $2 \times 2$. The research instrument used were bakiak game, interpersonal intelligence observation sheets and motor physical development tests. Research procedures are pretest, treatment, posttest, data processing, data analysis and conclusion. Meet the instrument validity and reliability standards. Data analysis techniques use descriptive data released by Mean, Median, Mode, frequency distribution table and histogram. Testing the analysis prerequisites that is normality and homogeneity data. From the results of data analysis obtained by this study shows the effect of bakiak game and interpersonal intelligence on physical motor of children in Khairani Kindergarten of Aceh Besar
\end{abstract}

Keywords :

Bakiaks; interpersonal intelligence; motor.

\section{Introduction}

One of the games that can improve the physical motor development, especially children's rough motoric is by bakiak game. If the children has motor skills which adequate their nerves, it will work to coordinate all body movements and follow certain rhythms so that the children will become a skilled and agile person.

Bakiak is one of the traditional games. The material is made from long wood like ice skates that have been crushed and given a few slippers on it, usually for 3-4 people. Bakiak usually play in groups or teams, with each team competing to get to the finish. This game tests dexterity, leadership, collaboration, creativity, insight and honesty. 
In addition to bakiak playing activities that can stimulate the physical development of motor children, it turns out there are other factors that also play an important role in improving children's psychic interpersonal intelligence. Interpersonal intelligence is the ability to understand and cooperate with others. According to Armstrong (2013: 39), the characteristics of children who have interpersonal intelligence are like socializing, being gifted as a leader, being a member of an organization, committee, or informal group among peers of their age, easy to get along, happy to teach other children informally, likes to play with friends his age, have two or more close friends, have good empathy or give more attention to others, many like friends and can understand the intentions of others even if hidden. The development of interpersonal intelligence is very important for children because it will be the basis when children associate with friends and the environment. That is why interpersonal intelligence is closely related to the learning process. Fun learning process determines the ability of children to behave and behave socially in harmony with religious norms, tradition morals, legal morals, and other moral norms that apply in society, especially in Aceh.

Children who have good gross motor skills will also have good mental development because children are able to adjust to the surrounding environment so that their confidence will continue to increase and will have a positive effect on cognitive motor skills.

\section{Review of Literature}

\subsection{Motoric}

Snowman (in Patmonodewo, 2000: 32) suggests the physical characteristics of preschool children (4-6 years), namely: the appearance and movements of preschool children are easily distinguished from children who were in the previous stage. The physical characteristics of preschoolers include: (1) preschoolers are generally very active. They already have mastery (control) of their bodies and really like the activities carried out by themselves. Give children the opportunity to run, climb and jump.

Snowman (in Patmonodewo, 2000: 35) "Early childhood is a different individual, unique, and has its own characteristics according to stages of age". At this time the stimulation of all aspects of its development has an important role for the task of further development. The cells of the body of an early child grow and develop very rapidly, the growth of the brain is undergoing extraordinary development, as well as its physical growth and development.

From this understanding, it is illustrated that early childhood is a child in the age range of 0-6 years which is carried out through the provision of educational stimuli to help physical and spiritual growth and development so that children have readiness to enter further education. In line with the National Education System Law No. 20 of 2003 concerning National Education System Article 28 paragraph 1, namely early childhood education, is held before the level of basic education.

Motor development is a process of growth and development of a children's ability to move. Basically, this development develops in line with the maturity of the nerves and muscles of the child. Thus, any simple movement is the result of a complex interaction pattern of various parts and systems in the body that are controlled by the brain. Motor skills are divided into two, namely gross motor and fine motor. Gross motor is an activity using large muscles which includes locomotor, non-locomotor and manipulative basic motion (Widarmi: 2008). 


\subsection{Interpersonal Intelligence}

The characteristics of children who have interpersonal intelligence according to Armstrong (2002: 33) are as follows: (a) have many friends, (b) a lot of socializing at school or in the environment, involved in groups outside school hours, (c) acting as the mediator of the family when a dispute occurs, (d) enjoys group play, (e) has great empathy for the feelings of others, (f) is sought as an advisor or problem solver by his friends, (g) enjoys teaching others, (h) appears to have lead talent.

By developing interpersonal intelligence in children from an early age will provide good benefits for children. According to Adi W. Gunawan (2006: 119), well-developed interpersonal intelligence will greatly determine one's success in life after he completes formal education, allows communication and understanding of others, understands different states of mind and moods, has the ability to form and maintain a relationship, and can have the ability to effect friends and are usually very prominent in doing group work.

\subsection{Bakiak Game}

According to Piaget in Benson (2004: 75) there are three levels of play; a). Playing mastery is a repetition of behavior, b). Playing symbolic, playing fake because it involves fantasy, playing roles and using symbols, c). Playing with rules, this game is important in the process of learning to determine what is right and what is wrong.

According to Moeslichaton (2004: 37), there are several classifications of play activities that are appropriate for early childhood, namely play activities in accordance with the dimensions of the children's social development and play activities based on the children's fondness. Play activities in accordance with the dimensions of the children's social development: (a). Playing Solitary, i.e. the child playing alone or can also be helped by the teacher. The researchers consider playing solitary as having an important function because each of these types of play activities $50 \%$ involves educational activities and 25\% involves rough muscle activities, (b). Playing in parallel, namely playing individually side by side, so there is no interaction between them, but there is imitation, (c). Associative Play, this happens when children play together, play ball together, play sand together, and so on.

Soebandiyah in Soejiono (2010: 18), there are several principles related to the development of play activities programs: a) relevance, existing curriculum, relevant to children's development, b) adaptation, curriculum paying attention and adapting science materials, there must be technology and art developing, c) continuity, curriculum arranged in a sustainable manner, step by step, d) flexibility, the existing curriculum must be understood, used and developed in a flexible manner, e) practicality and acceptability, the curriculum can provide convenience for practitioners and the community in implementing educational activities, f) feasibility, existing formulation must show the worthiness and alignment of children, g) accountability, the existing curriculum must be accountable to the community.

In addition, specifically, the development of play activities programs must: 1) it based on the principles of early childhood development, such as the principle of learning through play. 2) The process of early childhood learning activities carried out in a conducive environment both indoors and outdoors. 3) The process is carried out with a thematic and integrated approach. 4) The process or activity is directed at developing the potential of intelligence as a whole and integrated. Dekdikbud (2000: 32-33). So the learning program can function as follows (Sujiono, 2009: 139): 1) Developing all abilities of children. 2) Introduce children to the world around them. 
3) Introducing regulations and instilling discipline in children. 4) Provide opportunities for children to enjoy playing.

Development of Play Activities Program Sujiono (2010: 71-76) mentions the basis for developing play activities program models, including: planning of play activities and developing themes. The explanation is explained as follows; Planning play activities and theme development. Planning is implemented in a strategy of active, creative and fun play activities for children. Suparman in Sujiono (2010: 72) revealed that the development of learning strategies had determined the sequence of learning activities (play), methods, media and the determination of time to be used. Theme development, thematic development is a learning strategy that involves several fields of development to provide different experiences for children. Sujiono (2010: 76) suggests the principle of theme development namely: a) providing opportunities for children to be directly involved; b) activities involve all senses; c) build new knowledge and: d) provide opportunities to use the game to translate experience into understanding.

Learning design is made in such a way by considering various things. Researchers make an observant observation of everything or responses that appear during the learning process. The next step is to analyze the students (children) researchers. Some things that become the object of analysis for example: 1) the response of children who are also a product of learning; 2) method 3) learning material, 4) teacher and so on. So the results of the analysis can be used as a reference to make improvements or improvements of all aspects of the learning process that is taking place. After this is done then, a review, formulating learning objectives by taking into account the various competencies to be achieved from the learning process.

After the learning process is implemented, there is an evaluation action. Evaluation is done thoroughly, starting from the teacher, students, methods, materials and teaching materials. All these aspects will determine the learning outcomes that can be one indicator of the success of the learning process. Then, an evaluation is needed to measure the results of the process. This evaluation is continuously carried out until there is an increase or positive change in the development of students and achieving the objectives of the learning process (play).

Learning scenarios are made using the opening activities until the closing. The opening activity functions as a warm-up, filled with activities that encourage the child to start interacting with the school community. Usually these activities are carried out outdoors. After that, the activity continues in the room to play the core and at the same time closing.

The type of bakiak game is the bakiak of the coconut shell, if in Javanese they are known as jejangkungan, in Sundanese Bogor call it the name of the bakiak batok. Shell bakiak are a traditional game that was born from the agrarian culture of Sundanese Bogor. This traditional game uses props in the form of dried shell which has been halved. Making coconut shell bakiakis not difficult, at first the old coconut shell was split into two parts. Each section is given a holes right in the middle, then it connected to a rope and connected to the other shell. The rope used is a rope that has flexural properties making it easier when used. Shell bakiak are played individually. Usually also to be competed at the district and village level on 17 August.

Traditional games function to maintain values by inserting meanings in various properties, forms, and types of games. Breakthroughs that can be made through first entering into the PAUD curriculum as forming the soul of children. Children tend to more easily understand something that is taught through media play, rather than just listening to the teacher lecture. The characteristic 
of traditional games is that they tend to use or utilize tools or facilities in our environment without having to buy them. One of the conditions is high imagination and creativity.

\section{Research Methods}

The location of the study was conducted at Khairani Kindergarten in Aceh Besar located in Lubok Batee village, Ingin Jaya Subdistricr, Aceh Besar District. This study was conducted on 15 October to 15 December 2018. The research subject of children's group B which amounted to 30 people, consisting of B1 (15 people) and B2 (15 people). This study was conducted by using experimental methods and research design with treatment by level $2 \times 2$. The research instrument used were bakiak game, interpersonal intelligence observation sheets and motor physical development tests. Research procedures are pretest, treatment, posttest, data processing, data analysis and conclusion.

\section{Discussion}

After following a series of preprogrammed learning processes, data on physical motor development in the form of scores are used and analyzed from the average results of the evaluations of the three evaluators. In each group there are children who have good interpersonal intelligence and children who have good interpersonal intelligence. Already and not good interpersonal intelligence possessed by children is measured by observing interpersonal intelligence.

Data on motor physical development in group B children totaling 30 people, obtained scores between 20 to 24 , and the frequency distribution as shown in the table below.

\begin{tabular}{|c|c|c|c|c|}
\hline No & Score & Criteria & $\mathbf{F}$ & $\begin{array}{c}\text { Percentage } \\
(\%)\end{array}$ \\
\hline 1 & 20 & $\mathrm{BSH}$ & 2 & 6,7 \\
\hline 2 & 21 & $\mathrm{BSH}$ & 5 & 16,7 \\
\hline 3 & 22 & BSB & 6 & 20,0 \\
\hline 4 & 23 & BSB & 12 & 40,0 \\
\hline 5 & 24 & $\overline{B S B}$ & 5 & 16,7 \\
\hline \multicolumn{3}{|c|}{ Total } & 30 & $100 \%$ \\
\hline
\end{tabular}

Based on the table above shows that $23.4 \%$ (7 children) get a score of motor physical development with the assessment criteria Developing in Accordance with Expectations (BSH) and $76.7 \%$ (23 children) get a score of motor physical development with a Very Good Developing assessment criteria (BSB).

Interpersonal intelligence data in group B children totaling 30 people, obtained scores between 13 to 14, and the frequency distribution as shown in the table below.

\begin{tabular}{|c|c|c|c|c|}
\hline No & Score & Criteria & $\mathbf{F}$ & $\begin{array}{c}\text { Percentage } \\
(\%)\end{array}$ \\
\hline 1 & 13 & Yes / Able & 26 & 86,7 \\
\hline 2 & 14 & Yes / Able & 4 & 13,3 \\
\hline \multicolumn{3}{|c|}{ Total } & 30 & $100 \%$ \\
\hline
\end{tabular}


Based on the table above shows that $86.7 \%$ (26 children) obtained a score of 13 and $13.3 \%$ (4 children) obtained a score of 14 with the criteria of having good interpersonal intelligence abilities and being able to effecta children's physical motor development.

Bakiak playing data on group B children totaling 30 people, obtained scores between 23 to 27. Frequency distribution as shown in the table below.

\begin{tabular}{|c|c|c|c|c|}
\hline No & Score & Criteria & $\mathbf{F}$ & $\begin{array}{c}\text { Percentage } \\
(\%)\end{array}$ \\
\hline 1 & 23 & $\mathrm{BSH}$ & 2 & 6,7 \\
\hline 2 & 24 & BSH & 10 & 33,3 \\
\hline 3 & 25 & BSB & 8 & 26,7 \\
\hline 4 & 26 & BSB & 4 & 13,3 \\
\hline 5 & 27 & BSB & 6 & 20,0 \\
\hline \multicolumn{3}{|c|}{ Total } & 30 & $100 \%$ \\
\hline
\end{tabular}

Based on the table above, it is shown that $40 \%$ (12 children) get bakiak' score with the development criteria according to Expectations (BSH) and 60\% (18 children) get bakiaks' score with the criteria of Very Good Developing (BSB) score.

Test of Bakiak Regression and Interpersonal Intelligence on Motor Physical Development

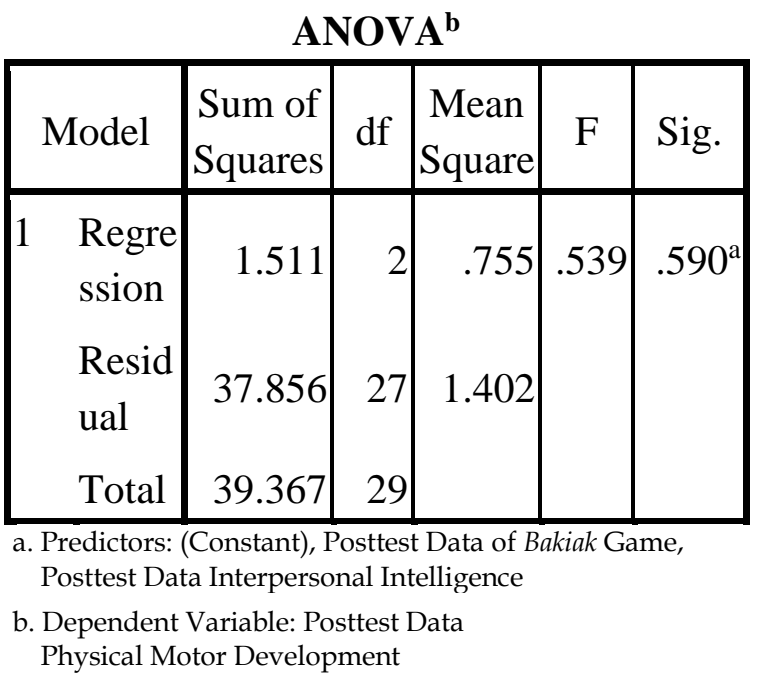

Merging inter variables above the value of sig. (2-tailed) is 5.90 . This shows that the value of sig. (2-tailed) $<0.05$. Therefore, it can be concluded that the hypothesis is accepted, meaning that the bakiak and interpersonal intelligence variables effect the children's physical motor development in group B of Khairani Kindergarten in Aceh Besar.

This study aims to look at the effect of bakiak and interpersonal intelligence on physical motor of children in Khairani Kindergarten of Aceh Besar

The results of the initial analysis of the implementation of the children's physical motor development so far in kindergarten tends to be carried out not systematically and not holistically. Activities are more oriented towards the results of learning carried out in the room only and pay less attention to the physical development process of motor children. As a result, the physical 
development of a children's motor does not take place simultaneously so there is a part of the development that is overlooked and lacks the attention of the educator / teacher.

Seeing the condition of a children's physical motor development that has not been carried out simultaneously, systemically and holistically, it is necessary to have a physical activity design that can accommodate the physical development needs of the motor. Mastery of motor skills does not occur automatically or suddenly but is an accumulation of experience and is influenced by the maturation process. That is, if the child is mature, the child can be trained easily and quickly because the children's nervous system is ready to respond normally.

Based on the results of data analysis of research conducted, the results obtained that the research hypothesis which states that there is an effect of bakiak play on physical motor (especially physical development of gross motor) of children. Judging from the change in score before and after being given treatment. Preliminary data / prior to being given treatment the average score of children's physical motor development is in the Undeveloped (MB) category and after being given treatment, there is an increase so that the children's physical motor development is in the Very Good Developing (BSB) category.

\section{Conclusion}

The study used an experimental method consisting of dependent variables that is physical motor development and free variables that is bakiak and interpersonal intelligence. Based on data obtained from the results of the analysis and testing of research hypotheses, it can be concluded:

1. There is an effect on the bakiak game on children's physical motor development in group B of Khairani Kindergarten in Aceh Besar.

2. There is an effect of interpersonal intelligence on children's physical motor development in group B of Khairani Kindergarten in Aceh Besar.

3. There is a significant the interaction of bakiak game and interpersonal intelligence on children's physical motor development in group B of Khairani Kindergarten in Aceh Besar.

\section{References}

Anzar, S. F., \& Mardhatillah, M. (2018). Analisis Kesulitan Belajar Siswa Pada Pembelajaran Bahasa Indonesia di Kelas V SD Negeri 20 Meulaboh Kabupaten Aceh Barat Tahun Ajaran 2015/2016. Bina Gogik: Jurnal Ilmiah Pendidikan Guru Sekolah Dasar, 4(1).

Adalilla, S. (2010). Pentingnya Pendidikan Anak Usia Dini.

Aqib, Z. et al. (2011). Penelitian Tindakan Kelas untuk Guru SD, SLB, dan TK. Bandung: Yrama Widya Armstrong, T. (2013). Kecerdasan Multifel di Dalam Kelas. Edisi Ketiga. Translated by Widya Prabaningrum, Dyah. Jakarta: Permata PuriMedia.

Amstrong. (2003), The art of HRD: Strategic Human Resource Management a Guide to Action Manajemen Sumber Daya Manusia Strategik Panduan Praktis untuk bertindak, alih bahasa oleh Ati cahayani.Jakarta: PT Gramedia.

Abidin, Y. (2009). Guru dan pembelajaran bermutu. Bandung: Rizqi Press.

Mardhatillah, M., \& Trisdania, E. (2018). Pengembangan Media Pembelajaran Berbasis Macromedia Flash Untuk Meningkatkan Kemampuan Membaca Siswa di SD Kelas II Negeri Paya Peunaga Kecamatan Meureubo. Bina Gogik: Jurnal Imiah Pendidikan Guru Sekolah Dasar, 5(1).

Sinulinga, A. (2014). Teori Dasar. Medan: Unimed Press

Soemiarti, P. (2003). Pendidikan Anak Pra Sekolah. Jakarta: Rineka Cipta 
Sujiono, Y., N. and Sujiono, B. (2010). Bermain Kreatif Berbasis Kecerdasan Jamak. Jakarta: PT Indeks. Suyadi. (2010). Psikologi Belajar Anak Usia Dini. Yogyakarta: PEDAGOGIA

Widarmi, D., et al. (2008), Kurikulum Pendidikan Anak Usia Dini, Jakarta: Universitas Terbuka.

Wiyani, A. (2012). Save Our Children From School Bullying. Jogjakarta: Ar-ruzz Media.

Wirdaningsih, W., \& Mardhatillah, M. (2016). Penerapan Media Audio-Visual Terhadap Keaktifan Pada Materi Hubungan Antara Sumber Daya Alam Dengan Lingkungan Siswa Kelas IV SD Negeri Pasi Teungoh Kecamatan Kaway XVI. Bina Gogik: Jurnal Ilmiah Pendidikan Guru Sekolab Dasar, 3(2).

Yamin, M. (2013). Strategi dan Metode dalam Model Inovasi Pembelajaran . Jakarta : Gaung Persada Press Group

Yus, A. (2011). Model Pendidikan Anak Usia Dini. Jakarta: Kencana. 